\title{
On the problem of studying shamanism in the Yakut and Korean culture
}

\author{
Fedot F. Zhelobtsov* \\ North-Eastern Federal University, 58 Belinskiy str., Yakutsk, 677000, Russian Federation
}

\begin{abstract}
The article is devoted to one of the discussed problems in religious studies, related to the question of whether shamanism is considered a world religion. This problem is closely related to the issues of ethnogenesis of both the Yakut and Korean peoples, which have not yet been completely resolved. Meanwhile, the realities are such that in the context of many studies, the word "shamanism" is used precisely in the meaning of religion. The relevance of the article is seen in the fact that comparative material on shamanism among different peoples will only contribute to the solution of many questions of shamanism. It is a fact that shamanism is still a cult of religion and a common link between the Yakuts and Koreans, who are in the same Altai linguistic environment, which had a huge impact on their culture and mentality. This closeness manifests itself in many areas of life, especially in the rich ancient folklore. Along with similar customs and traditions of shamanism in Yakutia and Korea, there are, of course, many differences caused mainly by the level of development of the structure of shamanism in both countries. The absence of any holistic concept of the history of the birth and evolution of shamanism significantly hinders the unified interpretation of its terms, up to discrepancy. The author hopes that the article will to some extent make up for the topic of Korean shamanism presented in the domestic literature.
\end{abstract}

\section{Introduction}

Shamanism is one of the earliest universal forms of religion and was widespread among most peoples in almost all parts of the planet. As noted by the Russian ethnographer and religious scholar L.Ya. Sternberg: "Not a single nation has been found that did not have any religious beliefs" [1, p. 183]. In the Great Soviet Encyclopedia, shamanism is defined as "an early form of religion among most peoples, which arose under the primitive order" [2, p. 278]. The researcher of shamanism P.V. Bersnev writes that "the classical figure of a shaman was inherent in the Bronze Age, when individual, personal shamanism appeared" [3, p. 19].

Elements of shamanism in a wide variety of forms have been present in all religious systems in the world. By absorbing these elements, world religions were much more successful in introducing themselves into closed Asian societies. Russian researcher V.M. Mikhailovsky writes, "Even if some other religion comes to the territory in which shamanism is widespread, then over time this religion will naturally absorb shamanic elements" [4, p. 5].

Archeological and ethnographic data indicate that shamanism on earth has existed for 20-30 thousand years, that is, almost simultaneously with the emergence of mankind. If we rely on the achievements of Siberian archeology and ethnography, then the possibility of the existence of the institution of shamanism in the Siberian and Far Eastern regions is already observed in the Bronze Age. The well-known researcher of shamanism Mircea Eliade emphasizes: "Shamanism is, first of all, a Siberian or Central Asian phenomenon" [5, p. 18]. The very word "shaman" entered the European languages from the Russian language. This word got into the Russian language in the 1st half of the 17th century from the language of the Evenks. Translated, it meant "wise man." In the meaning of a minister of religion, it first appeared in Russia in the written messages of Russian service people from Siberia at the end of the 17th century. And it got to Europe from Izbrand Ides and Adam Brandt, who traveled to China as part of the Russian embassy sent by Peter I [6, p. 8].

Among some researchers of shamanism, there is also a version that the shaman is "the successor of the totemic animal that evolved from the totemistic belief, during the transition from the Neolithic to the Bronze Age into the shamanic ideology and image" [7, p. 58]. But still, at present, the dominant theory is that shamanism originated and developed in the era of hunting and gathering.

Many Russian scholars of shamanism classify it as animism, while emphasizing that animism and shamanism are characteristic of peoples who are carriers of archaic cultures. A.A. Burykin writes, "This is the most religious system - animism, which is typical for the peoples of the Russian North, Siberia and the Far East" [8, p. 7].

\footnotetext{
*Corresponding author: fedotzhel@mail.ru
} 
The area of shamanism covers the countries of the Asia-Pacific region, where it is best preserved to this day in the Republic of Korea in the south of the Korean Peninsula. The Republic of Korea is the only state in the world where shamanism is a really existing phenomenon of the spiritual culture of modern Korean society [9, p. 187].

A clear understanding of this form of belief has not yet been achieved and, accordingly, the question of whether shamanism is a religion still remains open. Meanwhile, in the context of many studies, the word "shamanism" is used precisely in the meaning of religion. Undoubtedly, this is due to the existence of many religious cults, closely bringing it closer to classical religions. It lacks scriptures like the Bible or the Koran. There is no unity in the interpretation of its terms [10, pp. 77-82]. But another thing is quite obviousshamanism is an obligatory and integral part of religion. It can be figuratively said that if religion is a reflection of the evolution of human society, then shamanism is the childhood of mankind.

According to M. Hakkorainen, shamanism, of course, is "a kind of connecting link between the groups of indigenous peoples of the circumpolar region in different countries. But, first of all, shamanism remains a common base, which contributes to the entry of local shamans into the international arena" [11, p. 36-37].

\section{About Yakut shamanism}

Most Russian researchers are unanimous in the opinion that the most ancient customs and cults associated with shamanism can be observed today among the Yakuts and Altai.

Although Yakut shamanism is today the most studied in Siberia and the Far East, nevertheless, researchers have always noted a large difference between northern and southern shamanism among the Yakuts, due to the early separation of the northern Yakuts from the rest of the population in the south [12, p. 331-332].

There was a time in Yakutia when shamans were prohibited and persecuted. During the years of repression, the deprivation of the voting rights of shamans, and even all their relatives, was massively practiced [13, p. 19]. However, the people have always revered them and are still revered.

In modern Yakutia, elements of shamanism have been legally included since 1991 into the Ysyakh public holiday, which is widely celebrated in June every year. However, V.I. Kharitonova is convinced that attempts to form a shamanic religion in Russia are unlikely to be successful if they are not supported by socio-economic transformations [14, p. 50].

Recently, the topic of shamanism has again acquired an acute controversial character due to the emerging new paradigm in the theory of ethnogenesis and the spiritual life of the Yakut people. Yakut scientists-historians A.N. Alekseev and A.I. Gogolev, relying on numerous evidences from archeology and ethnography, are convinced that the Yakuts (self-name - Sakha) as a people have formed in the Middle Lena as a result of mixing with aboriginal tribes in the 2 nd half of the 16th century. At the same time, they emphasize the predominant influence of the Turkic beginning as evidence of the southern origins of the Sakha people [15, p. 66-67], [16, p. 22].

Leaving aside the no fewer complex problems of the ethnogenesis of the Yakut people, here I would like to dwell on the question of the place of shamanism in the spiritual life of the Sakha as a factor closely related to the history of the people.

Regarding the dispute about the name of the ancient religion of the Turkic peoples-shamanism or Tengrianism-I would like to mention the famous Turkish scholar Abdulkadir Inan, whose work "Shamanism Yesterday and Today" is a reference book for researchers of shamanism all over the world.

In his work, Abdulkadir Inan made extensive use of interesting data on shamanism from the records of Arab, Persian travelers and Chinese sources. According to the deep conviction of a Turkish researcher, "Yakut and Altai shamanism cannot be considered an ancient Turkic religion" [17, p. 1].

The main argument of the Turkish scholar is that the ancient religion of the Turks, in comparison with the shamanism of these peoples, stood at a much higher degree of development and perfection. The pledge of this was the rich history of the ancient Turkic tribes, who in their time created powerful state formations and, accordingly, had a deeper ideological basis. At the same time, he admits that the ancient Turks were undoubtedly shamanists. Moreover, he also admits that the representatives of the earliest shamanism were the northern Turkic tribes. At the same time, he emphasized: "These were the ancestors of the modern Yakuts and the grandchildren of the Kurykans" [Ibid, p. 11]. The Turkish scientist, confirming the fact of the arrival of the ancestors of the Yakuts from the south, in his work still did not give a specific name for the religion of the ancient Turks. With regard to the widespread name of the highest Yakut deity "tañara", the scientist designated it only as a sign of ordinary idolatry.

Thus, the name of the religion of the ancient Turks has not been determined to this day.

R.N. Bezertinov, a recognized Russian scholar of shamanism and Tengrianism. He called the religion of the ancient Turks "the worldview of the people" [6, p. 8]. At the same time, the scientist does not deny the fact that shamanism as the earliest form of religion preceded the formation of religion among the ancient Turks. Thus, R.N. Bezertinov, like Abdulkadir Inan, does not give the exact name of the ancient Turkic religion.

In the light of the views of these leading scholars in the study of shamanism, one cannot but say that the view of a number of Yakut researchers who, on the one hand, adhere to the theory of the autochthonous origin of the Yakut ethnos, has a right to exist, but, on the other hand, do not insist on direct relationship Yakut shamanism with the religion of the ancient Turks. According to them, long before the arrival of the Turkic-speaking tribes to the Middle Lena, the Yakuts already had their own national religion, Aiyy, with many of its shamanservants. S.I. Nikolaev writes, "This religion was born at 
the very dawn of mankind and consisted by no means of only shamanism" [18, p. 9]. "Pure shamanism itself," he writes further, "does not at all belong to the Yakut religion. This is only a fellow traveler of religion" [Ibid, p. 25]. The fact remains that Russian explorers in the 17 th century found an already established local religion here $[19$, p. 41$]$. In the lists of yasakpayers, almost every tenth figured as a professional shaman [18, p. 14].

\section{About shamanism in Korea}

Anyone interested in the spiritual life of Korean society always has a genuine interest in everything that is associated with shamanism in this country. This interest is fueled, of course, by the religious closeness of the distant past of our peoples, which was based on shamanism-the core of the spiritual life of the entire Far Eastern civilization.

For various reasons, the topic of Korean shamanism is not sufficiently represented in the Russian-language scientific literature. For many years, there have been no scientific ties, field research opportunities and the exchange of scientific literature between Russia and the Republic of Korea.

Korean scholars agree that the origins of Korean shamanism should be sought in North Asia. This is confirmed by numerous archaeological artifacts from the Bronze Age found in Korea, similar to those in Yakut. The fact that the primitive beliefs of Korea were derived from ancient Siberian shamanism is clearly traced in Korean mythology. In prehistoric times, shamanism served as the only form of religious beliefs of the Korean ethnos.

For the first time, shamanism was mentioned in historical information about the proto-Korean states of Buyo and Goguryeo. For many centuries shamanism (in Korean "musok") was the main faith of Koreans, who spiritualized the entire visible nature, inhabiting it with countless spirits and demons. It is noteworthy that the musok turned out to be very viable and, despite the penetration of Buddhism, Confucianism and Christianity into the Korean Peninsula, it is still well preserved in Korean society and had a huge impact on the Koreization of alien religions. At the same time, the spiritual principle has always had an absolute predominance over the physical.

Koreans have traditionally revered the spirits of the Earth, Moon, Sky, stars (especially the Big Dipper and Venus) from ancient times. The pantheon of shamanism was truly enormous. Only through sacrifices could the good disposition of all spirits be maintained. The wellbeing of a person depended entirely on his ability to appease good spirits. There is reason to believe that in prehistoric times, even human sacrifices were made to propitiate spirits. But with the penetration of Buddhism, the character of Korean shamanism softened.

In Korea, shamanism experienced a long period of oppression during the Japanese occupation, associated with the ideological suppression of the spiritual values of the Korean people. Its elements have been absorbed by all religions that have penetrated the peninsula. As a result, shamanism in Korea remained not only a kind of basis for the religious beliefs of Koreans, an integral part of the national culture, but also continued equal coexistence with alien religions. In the Republic of Korea today, shamanism is preserved at the state level. This was largely facilitated by the freedom of religion proclaimed after the Second World War. At present, shamanism, of course, has largely lost its former positions, becoming in fact a decorative element of the spiritual life of Koreans. Ritual rituals of shamanism can be seen mainly during folklore festivals or folk festivals. In modern Korea, there are over ten million adherents of shamanism, whose religious needs are served by up to one hundred thousand shamans. There are about a hundred shaman temples in Seoul alone. The authorities support shamanism as an integral part of traditional Korean heritage. The most famous shamans are even awarded the honorary title of "Man of National Treasure". Koreans perceive shamanism as the only "ancestral" religion and an integral part of their cultural heritage.

\section{Comparative analysis of shamanism in Yakutia and Korea}

In Korean, as well as in Yakut, shamanism, the spiritual principle has always had and has an absolute predominance over the physical principle. All objects and phenomena of nature have their own master spirit, which testifies to the powerful influence of ancient animism. Numerous archaeological finds in Korea, adorned with religious symbols such as the royal crown, tambourine, knife, mirror, date back to the Bronze Age. Such items are still widely used by shamans of Northeast Asia (including Yakut). Unfortunately, very few materials on the spiritual life of the Proto-Koreans of the Bronze Age have survived. Due to the fact that the scattered religious rites and ideas were not united at that time into a single and coherent system, Korean shamans and magicians did not yet become professional clergymen.

According to Korean shamanism, the human soul, as in Yakut, consists of three components: Hong, Baek and Yong. Hon - "rational soul" after death departs in a memorial tablet with a name, Pek - "bodily soul" goes to the grave, and Yong - "heavenly soul" flies to Heaven to ten judges (compare with souls in Yakut shamanism Iye-kut, Buor-kut, Salgyn-kut).

Yakut and Korean shamans are intermediaries between deities and spirits, with the help of which they help people. Moreover, the shaman could be an intermediary only during the ritual. The Korean shaman, like the Yakut, did not possess spiritual strength, but at the same time, using a special method, he usually fell into ecstasy, with the help of which he communicated with spiritual beings.

The hierarchy of shamans in Korea is distinguished by a more complex structure than in Yakutia [20, p. 78]. Among the Korean shamans, pansu stood out - blind sorcerers and mudans (women-shamans). Pansu at all times enjoyed a special veneration in Korea, since 
blindness was seen as a sign of special chosenness. They were considered the lords of the demons, while the mudanas could only appease them. Pansu was mainly engaged in fortune telling and divination. When divining to pansu, they used fortune-telling boxes, a bamboo or copper pipe, and sold amulets. In addition, witchcraft was considered a hereditary craft among pansu and was often the only means of subsistence. How profitable this craft was can be seen from the fact that the parents of children born blind were considered happy, since the earnings of these future pansu fully provided their old age. The blind who entered the Pansu corporation were required to undergo tests for three years, and during this time they were initiated into all the secrets of witchcraft. They had to professionally know all the strengths and weaknesses of the life of different classes of Korean society [21, p. 271-273].

The most numerous group of Korean shamans is mudans. Mudans were usually women, although men рахити - are also ranked among them. It should be noted that in Korean shamanism the "female" factor definitely dominates over the male one. The Korean researcher $\mathrm{K}$. $\mathrm{OH}$ believes that the main reason for this factor was the Confucian patriarchy during the reign of the Joseon dynasty (1392-1897). According to Confucian ideology, the lower classes and women were excluded from Confucian ceremonies, which led the latter to search for their religion [22, p. 71]. The functions of mudan were considered so peculiar only to women that even paxumu (male shamans) had to dress in a woman's dress during the performance of shamanic rituals. Mudans, as a rule, broke all their family and social ties and were considered expelled from society. For the most part, they led a hermitic life and were specially invited to perform rituals of sacrifice, ceremonies of purification, and the expulsion of diseases. Their homes are still outside the city walls.

V.L. Seroshevsky also noted that the female element in witchcraft among the Yakuts played a significant role. He personally observed in the Kolyma district how shamans during the ritual put on a woman's dress [23, p. 609].

Many similarities can be found when comparing the ways of acquiring the status of a shaman from both peoples. In Korean, as in Yakut shamanism, only a person marked by the will of the gods or spirits and who had a hereditary gift in his family or came into contact with a deceased shaman could become a shaman. Such a person, from the very moment of his birth, had some special signs and passed the test of "shamanic disease" caused by the fact that his soul was carried away for special education by spirits into one of the three worlds of shamanism. "Shamanic disease" in Korean is called "shinbyon". This morbid condition, as in Yakut shamanism, is the main prerequisite for the formation of a shaman. But with no preparation, no skill, an ordinary person will not be able to become a real shaman-he will only be able to imitate a shaman. Any person can, in principle, undergo this disease, but most often the blood relatives of the shaman suffer from it. The disease can last from one month to three years. If a woman-shaman begins to visit a spirit in love with her, then the life of her husband becomes unbearable. "Shamanic disease" persists in Korea to this day. She torments a person until he becomes a real shaman, makes himself an altar and masters the shamanic ritual. An altar is a must-have for every Korean shaman house. Only the shaman to whom this altar belongs can touch the altar and the things in it.

In Yakut shamanism, after the death of a shaman in the family, the "shamanic disease" also infiltrates one of his descendants, into which the soul of the deceased shaman must move. The person chosen by the spirits undergoes an incurable "shamanic disease", goes through such tests as the well-known shredding of the body "ettenia". Everything started the same way with a serious illness of the applicant, in a dream, when spirits came to the person, cut off his head, impaled him on a stake, cut the body into small pieces and laid them out in different directions of the cardinal points. The spirits chewed on these pieces, which were sure to go to other participants in the ettenia. Thus, shredding or cutting the body is the sacrifice of body parts and blood of the future shaman to the spirits, which will help him in the future [24, p. 67].

In the Yakut shamanism, the phenomenon of "meneryachenie" is also known - the disease got this name from the Yakut word "menairier", which translates as "bliss", "makes strangeness". "Meneryachenie" has been known in Yakutia since the 19th century. It was a psychopathological state in which a person, regardless of his own desire, copies the actions and words of others. He obeys any orders from the outside coming from another person. A sick person, as a rule, despite attempts to stop him, falls into a rampage and rushes towards the north - to the Pole Star. To this day, modern medicine has not found the causes of this disease [25, p. 28-29].

There are many similarities between Yakut and Korean shamanism in conducting the main rite kamlanie, which has remained unchanged for many millennia. It is noteworthy that this action is a common link in shamanism in all corners of the world. The famous Russian researcher of shamanism I.A. Kryvelev, believing that it is based on polydemonism, characterizes the ritual as follows: "It is a cult act arising from belief in demons and in the reality of human relations with them through the mediation of a shaman. Shamanism, from this point of view, is nothing but the cult side, or the cult system of polydemonism" [26, p. 47].

The essence of the kamlania since ancient times was that the spirits entered the body of the shaman, and he began to speak on their behalf, and his soul went on a journey into the kingdom of spirits. The main functions of the ritual are also similar: the propitiation of good spirits, including the spirits of the home and family; worship of the patron spirits of the community; prayer for health; expulsion of evil spirits; seeing off the souls of the dead to heaven. German scientist W. Eberhard colorfully wrote about the deep antiquity of the custom of rituals in the Mongol and Turkic tribes as early as the 3rd century AD., when the rite of sacrifice was performed by women-shamans with tambourines in their hands [27, p. 43]. In general, the rite of ritual in Yakut and Korean shamanism is the same. The main difference is only in the attributes of the ritual: instead of a tambourine, Korean shamans use bells, swords or 
bamboo poles. S.A. Tokarev described the ritual of the Yakut shamans in the following way: "The meaning of the ritual consists in hypnosis of others and selfhypnosis, thanks to which the shaman not only makes the audience believe in his supernatural abilities, but usually believes in them and himself experiences hallucinations during the ritual" [28, p. 271].

During the ritual, the Yakut shaman actively attracts helpers-spirits - the owner of the hearth (fire) or the owner of the area. Sometimes the spirits of Evenk shamans act as their assistants. It is noteworthy that the Yakut shaman speaks with them in Evenk. Spiritshelpers of shamans had a specialization in diseases that they had to treat [23, p. 604-605].

During the ritual, the Korean shamans, like the Yakut, entered a state of trance and communicated with the spirits, changed their clothes several times. It is believed that also in a trance state, the Korean shaman visits the Lower World (the world of spirits), the Upper world (the world of the gods) and the Middle World (the world of earthly spirits). The shaman puts on a ritual costume and can, during ecstasy, turn into a wild beast and pounce on other shamans.

Ornithological motives similar to Korean ones are quite common in Yakut folklore. In the Korean religious festival Suritnal, the eagle (suri) carries the shaman's soul into the spirit realm. A similar plot is known in the Yakut legends.

Along with similar customs and traditions, there are, of course, differences.

The greatest difficulty due to the lack of a unified approach to the study of the history of shamanism today is the different interpretation of specific terms related to shamanism. Even with regard to the very term "shaman", which arose from the Evenk language and has become a commonly used ethnographic term, according to the well-known Russian researcher of shamanism A.A. Burykin, until recently there was a serious competitor the Yakut name "oyuun". However, it did not take root in scientific terminology and the word "shaman" became common [29, p. 3]. According to R.N. Bezertinova, "neither the ancient Turks, nor the modern Altai-Sayan peoples not only did not use, but did not even know the term "shaman" [6, p. 8].

The role of female clergymen in Yakut shamanism is clearly poorly studied. And this, despite the fact that researchers of Yakut shamanism constantly noted the predominance of the number of shaman women in Yakutia [30, p. 176]. There is even the term "udaganka", which denoted the female clergyman. Udaganki are constant heroes of the Yakut epic Olonkho, they help heroic heroes in their struggle against the abaasy (devils) of the lower world. "White" shaman women-aiyy udagana-together with aiyy oyun performed rituals at the national holiday-ysyakh. The famous Yakut researcher of shamanism G.V. Ksenofontov noted the existence among the Yakuts of aiyy dzhargal udaganaa ringing "white" shaman, who occupied an intermediate position between "white" and "black" shamans. These shaman women performed prayers for the gift of children, offspring of cattle and horse [31, p. 41]. However, among the Sakha people, the most revered central figure of the Aiyy cult is the goddess Aiyysyt, the female progenitor.

At the same time, G.V. Ksenofontov noted the inferior position of female shamans in comparison with male shamans, which cannot be said about female shamans among Koreans. In general, the activities of the Yakut Udagan women were limited to the administration of female rituals and related to the magical protection of the family from various adversities.

It is noteworthy that Korean shamans, like Yakut shamans, focus on healing. This feature of the Yakut shamans was mentioned by S.I. Nikolaev (Somogotto) [19, p. 28]. A.K. Chirkova describes many interesting facts from the medical practice of the famous Yakut shaman K.I. Chirkov. In her opinion of a professional doctor, shamanic treatment is a systemic-integrated approach to a person, based on a psychological principle, and may well be used in modern medical practice [32, $\mathrm{p}$. 135].

Historian-ethnographer A.I. Gogolev gives such a description of the Yakut shaman-healer from the work of V.L. Seroshevsky: "A sorcerer who decides ... to fight not because of material benefits, but also for the sake of alleviating the suffering of his neighbor, a sorcerer by vocation, a believer ... who gets down to business with some kind of enthusiastic disregard for his own safety and is illuminated by the high light of the victim — such a sorcerer always makes a tremendous impression on the audience" [16, p. 81].

The language of the Yakut shamanic ritual poetry has been studied very little. Meanwhile, shamans mostly worked exclusively through the algys (rite of blessing).

\section{Conclusions}

In the light of discussions on the problem of whether shamanism should be considered a world religion, a comparative analysis using the example of shamanism in different countries and among different peoples will only contribute to solving this complex and multifaceted problem.

The choice of studying shamanism in its Yakut and Korean versions is determined by such important factors as the dominant hypothesis about the northern origin of the Korean ethnos on the basis of archaeological artifacts and religious beliefs of the peoples of the entire Far Eastern area, as well as the finding of Koreans and Yakuts in the same Altai linguistic environment.

The absence of any holistic concept of the history of the birth and evolution of shamanism, the absence of any sacred books, customs and traditions generally accepted as in other religions, a single interpretation of its terms continue to generate new difficulties today, even to the point of discrepancy.

At the same time, there are many striking similarities between Yakut and Korean shamanism in dogma, in practical functions (rituals, treatment).

In Yakutia, as in Korea, shamanism, being an indigenous religion, is not officially recognized today. 
If the dominant of the sacred role of womenshamans, despite the persecution, is generally defined in Korea, then it is not in Yakutia.

The author, without pretending to make any final conclusions, hopes that his attempt to compare the materials on shamanism in Yakutia and Korea will give an opportunity to consider the problems posed somewhat more broadly.

It is impossible to talk about shamanism without considering its historical characteristics. In Korea, shamans have achieved the status of living guardians of folk traditions and customs, and in Yakutia they are on the verge of extinction. There is, of course, an objective historical reason for this-the mass acceptance of Orthodoxy by the Yakut population, which has nothing in common with shamanism.

It is shamanism in Korea that plays a significant role in preserving the national traditional culture; Moreover, this role is positive in the sense that it has become an organic part and a stimulus for the development of the entire cultural life of Koreans, preserving their centuriesold traditions. It is safe to say that as long as Koreans maintain their traditional way of life, shamanism will live for so long.

\section{References}

1. L. Ya. Sternberg. Primitive religion in the light of ethnography. Research, articles, lectures (Moscow: Librokom, 2012).

2. A.M. Prokhorov (ed), Great Soviet Encyclopedia (Moscow: Sov. encyclopedia, 1978).

3. P.V. Bersnev. Historical aspects of shamanism Historical, philosophical, political and legal sciences, cultural studies and art history. Questions of theory and practice. 9 (71), 19-23, (2016).

4. V.M. Mikhailovsky. Shamanism (Moscow: Association of Skoropechatnya A.A. Levenson, 1892)

5. M. Eliade. Shamanism: Archaic Techniques of Ecstasy (Kiev: publishing house unknown, 1998).

6. R.N. Besertinov. Ancient Türkic worldview "Tengrianism" (Kazan: RIC "School", 2006).

7. A.F. Anisimov. Stages of development of primitive religion (Moscow-Leningrad: Nauka, 1967).

8. A.A. Burykin. Faith in spirits. How many souls a person has (St. Petersburg: Azbuka-Classic. Petersburg Oriental Studies, 2007).

9. Y. Jongsung. Korean cultural property protection law with regard to Korean Intangible heritage Museum 221-222, 56(1-2), 180-188 (2004).

10. F.F. Zhelobtsov. On the history of shamanism terminology, Bulletin of NEFU. 11(4), 77-82, (2014).

11. M.V. Hakkarainen, S.A. Shtyrkov Shamanism Religious life of Siberia and the Far East (St. Petersburg: Nestor-History, 2015)

12. G.V. Ksenofontov. Uraanghai Sakhalar. Essays on the ancient history of the Yakuts, (Yakutsk:
National Publishing House of the Republic of Sakha (Yakutia), 1992).

13. P.N. Ilyakhov-Hamsa. Fight against shamanism in Yakutia (1920-1930) (Yakutsk: Republican House of Folk Art (RNDT), 1995).

14. V. Kharitonova. Revived shamanism in the social life of Russia Electronic Journal of Folklore,. 62, 37-54 (2015).

15. A. N. Alekseev. To the question of the origin of the Yakut people Coll. sci. works. Series: Philology. (Yakutsk: YSU publishing house, 1994).

16. A.I. Gogolev. History of Yakutia (Yakutsk: publishing house NEFU, 2015).

17. I. Abdülkadir. Shamanism in history and today. Materials and research (Ankara: Türk Tarih Kurumu basimevi, 1995)

18. S.I. Nikolaev (Somogotto). From the history of religion Aiyy (Yakutsk: Olonkho, 2010).

19. S.I. Nikolaev (Somogotto). The customs of the Sakha people (Yakutsk: NIPK Sakhapoligrafizdat, 1996).

20. F.F. Zhelobtsov. Religions of the countries of the Asia-Pacific region. (Yakutsk: NEFU Publishing House, 2013).

21. S.A. Tokarev. Religion in the history of the peoples of the world (Moscow: Publishing House of Political Literature, 1986).

22. K. OH. Korean shamanism - the religion of women, International Journal of Korean Humanities and Social Sciences 2, 71-85, (2016). DOI: http://dx.doi.org/10.14746/kr.2016.02.05.

23. V.L. Seroshevsky. Yakuts. Experience of ethnographic research (Moscow: ROSSPEN, 1993).

24. R.I. Bravina. Shamans are the chosen ones of Heaven and Spirits (Yakutsk: Bichik, 2018).

25. G. Orlova. Call of the North Star, Secrets and riddles. 11, 35, (2014).

26. I.A. Kryvelev. History of religion (Moscow: Publishing house "Mysl", 1975).

27. W. Eberhard. China's shimal neighbors (Ankara: Türk Tarih Kurumu, 1942).

28. S.A. Tokarev. Early forms of religion and their development (Moscow: Publishing house of political literature, 1990).

29. A.A. Burykin. Shamans. Those who are served by spirits (St. Petersburg: Classical ABC. Petersburg Oriental Studies, 2007).

30. S.V. Bakhrushin and S.A. Tokarev (eds) Yakutia in the 17th century. Essays (Yakutsk: Yakutsk book publishing house, 1953)

31. G.V. Ksenofontov. Shamanism (Yakutsk: TPF "North-South", 1992).

32. A.K. Chirkov. My father is a shaman (Yakutsk: Yakutia Publishing House, 2006). 